\title{
New tricks of well-known aminoazoles in isocyanide-based multicomponent reactions and antibacterial activity of the compounds synthesized
}

\author{
Maryna V. Murlykina ${ }^{1,2}$, Maryna N. Kornet ${ }^{3}$, Sergey M. Desenko ${ }^{1,4}$, \\ Svetlana V. Shishkina ${ }^{1,4}$, Oleg V. Shishkin ${ }^{1}$, Aleksander A. Brazhko ${ }^{3}$, \\ Vladimir I. Musatov ${ }^{1}$, Erik V. Van der Eycken ${ }^{2}$ and Valentin A. Chebanov ${ }^{* 1,2,4}$
}

\section{Full Research Paper}

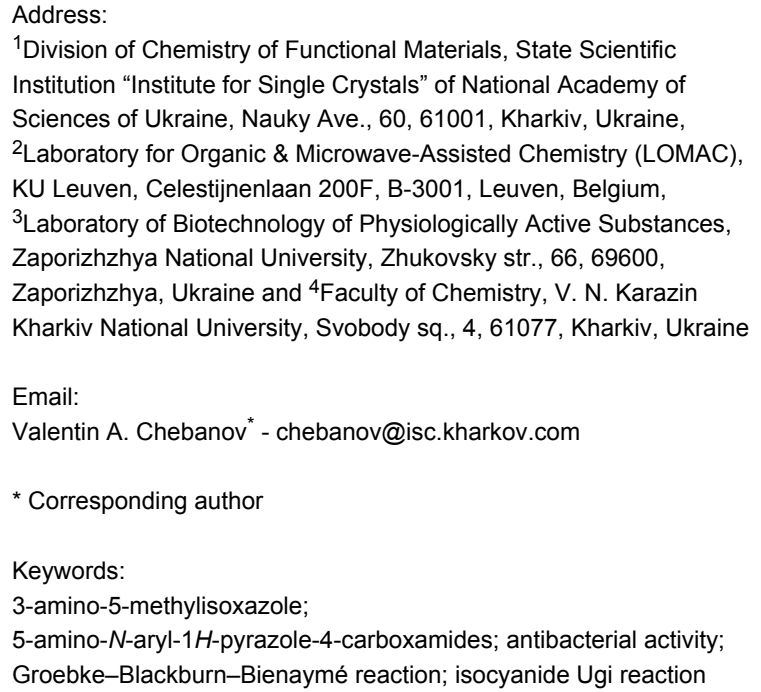

${ }^{1}$ Division of Chemistry of Functional Materials, State Scientific Institution "Institute for Single Crystals" of National Academy of Sciences of Ukraine, Nauky Ave., 60, 61001, Kharkiv, Ukraine, 2Laboratory for Organic \& Microwave-Assisted Chemistry (LOMAC), KU Leuven, Celestijnenlaan 200F, B-3001, Leuven, Belgium, ${ }^{3}$ Laboratory of Biotechnology of Physiologically Active Substances, Zaporizhzhya National University, Zhukovsky str., 66, 69600, Zaporizhzhya, Ukraine and ${ }^{4}$ Faculty of Chemistry, V. N. Karazin Kharkiv National University, Svobody sq., 4, 61077, Kharkiv, Ukraine

Email:

Valentin A. Chebanov* - chebanov@isc.kharkov.com

${ }^{*}$ Corresponding author

Keywords:

3-amino-5-methylisoxazole;

5-amino- $\mathrm{N}$-aryl- $\mathrm{H}$-pyrazole-4-carboxamides; antibacterial activity;

Groebke-Blackburn-Bienaymé reaction; isocyanide Ugi reaction

\author{
Beilstein J. Org. Chem. 2017, 13, 1050-1063. \\ doi:10.3762/bjoc. 13.104
}

Received: 29 January 2017

Accepted: 02 May 2017

Published: 31 May 2017

Associate Editor: T. J. J. Müller

(C) 2017 Murlykina et al.; licensee Beilstein-Institut.

License and terms: see end of document.

\begin{abstract}
The well-known aminoazoles, 3-amino-5-methylisoxazole and 5-amino- $N$-aryl-1H-pyrazole-4-carboxamides, were studied as an amine component in Ugi and Groebke-Blackburn-Bienaymé multicomponent reactions. The first example of an application of aminoazoles in an Ugi four-component reaction was discovered and novel features of a Groebke-Blackburn-Bienaymé cyclocondensation are established and discussed. The heterocycles obtained were evaluated for their antibacterial activity and several of them demonstrated a weak antimicrobial effect, but for most of the compounds a 30-50\% increase in biomass of Gram-positive strains (mainly B. subtilis) compared to control was observed.
\end{abstract}

\section{Introduction}

An intensive progress in pharmaceutical and medicinal chemistry, as well as in the generation and improvement of medicinal technologies has led to defeating a wide scope of diseases.
However, we are still facing the problem of untreated ones, together with the appearance of unknown disorders and the dramatical growth of antimicrobial resistance caused by the 
continuous evolution of microorganisms [1-5]. Therefore, there is urgency in careful screening the chemical space with the aim of finding new biologically active structures. Modern chemistry offers several approaches, for instance, diversity oriented synthesis (DOS) for the generation of diverse compound libraries [6-8]. From this point of view, multicomponent reactions (MCRs), including isocyanide-based MCRs as the Ugi four-component reaction (Ugi-4CR) and the Groebke-Blackburn-Bienaymé reaction (GBB-3CR) in combination with postcyclizations are powerful tools to access diversity as well as complexity in a one-pot procedure; in this way they largely cover the available chemical space [9-26]. The imidazoheterocyclic scaffold represents a promising area for the discovery of novel synthetic drug molecules [27-52]. Particularly, there are several drugs containing the imidazo[1,2-a]pyridine moiety such as zolpidem (treatment of insomnia) and olprinone (cardiotonic drug) and a lot of compounds in biological testing and preclinical evaluation such as soraprazan (clinical antiulcer compound), necopidem (sedative effect), and saripidem (anxiolytic) [27]. The activity of different imidazoheterocycles was also studied against migraine [30], gastric [31,32], heart [3436], viral diseases [37-41] and an array of neurological syndromes [52]. The imidazo[1,2-b]pyrazole core shows also a pharmacological potential. Among others, anti-inflammatory [28,43], antiviral [39,44], antidiabetic [45] effects and cancer cell growth-inhibitory features should be mentioned [29,46-48].

Ugi-4CR has been applied in the synthesis of natural products, as bicyclomycin, furanomycin, penicillin etc. [53]. The high combinatorial potential of Ugi-4CR together with the ability to incorporate a variety of functionalities and modifications extend its application for the generation of organic compound libraries, following hit-to-lead optimization, choosing the hit structure and final marketed drug production [54-58]. Moreover, it has been acknowledged that the combination of two privileged scaffolds in a single molecule (e.g., the combination of a peptidomimetic structure with an azole fragment [59]) potentially creates more active, new entities with unusual bioproperties $[20,60,61]$. In addition, the application of polyfunctional reagents in Ugi-4CR opens ways to different post-cyclization reactions, thereby broadening the scope. Thus the Ugi-4CR involving substituted propiolic acids, can be followed by electrophilic ipso-iodocyclization [62] or transition-metal-initiated [63-68] and metal-free cyclizations [69,70].

There are examples of using aminoazoles as an amine component in GBB-3CR (Scheme 1). They mostly involve different substituted 3-amino-1,2,4-triazoles [71-75] and 2-amino(benzo)thiazoles [71,72,76-88]. Several publications deal with 2-amino-1,3,4-thiadiazoles [71,83,84,89,90], 2-aminoimidazoles [71,72,91,92], 2-aminoxazoles [71] and 1,2,5-oxadiazole-3,4-diamine [93] with the formation of imidazoazoles. Among the pyrazoles only 5-amino-3-methylpyrazole, 5-aminopyrazole-4-carbonitrile and ethyl 5-aminopyrazole-4carboxylate are described in GBB-3CR [29,71,83,84,94-96]. To the best of our knowledge, there is no information about the reactivity of aminoazoles as an amine component in Ugi-4CR.

Taking into account the above-mentioned facts, several aminoazoles, whose reactivity in isocyanide-based reactions had not

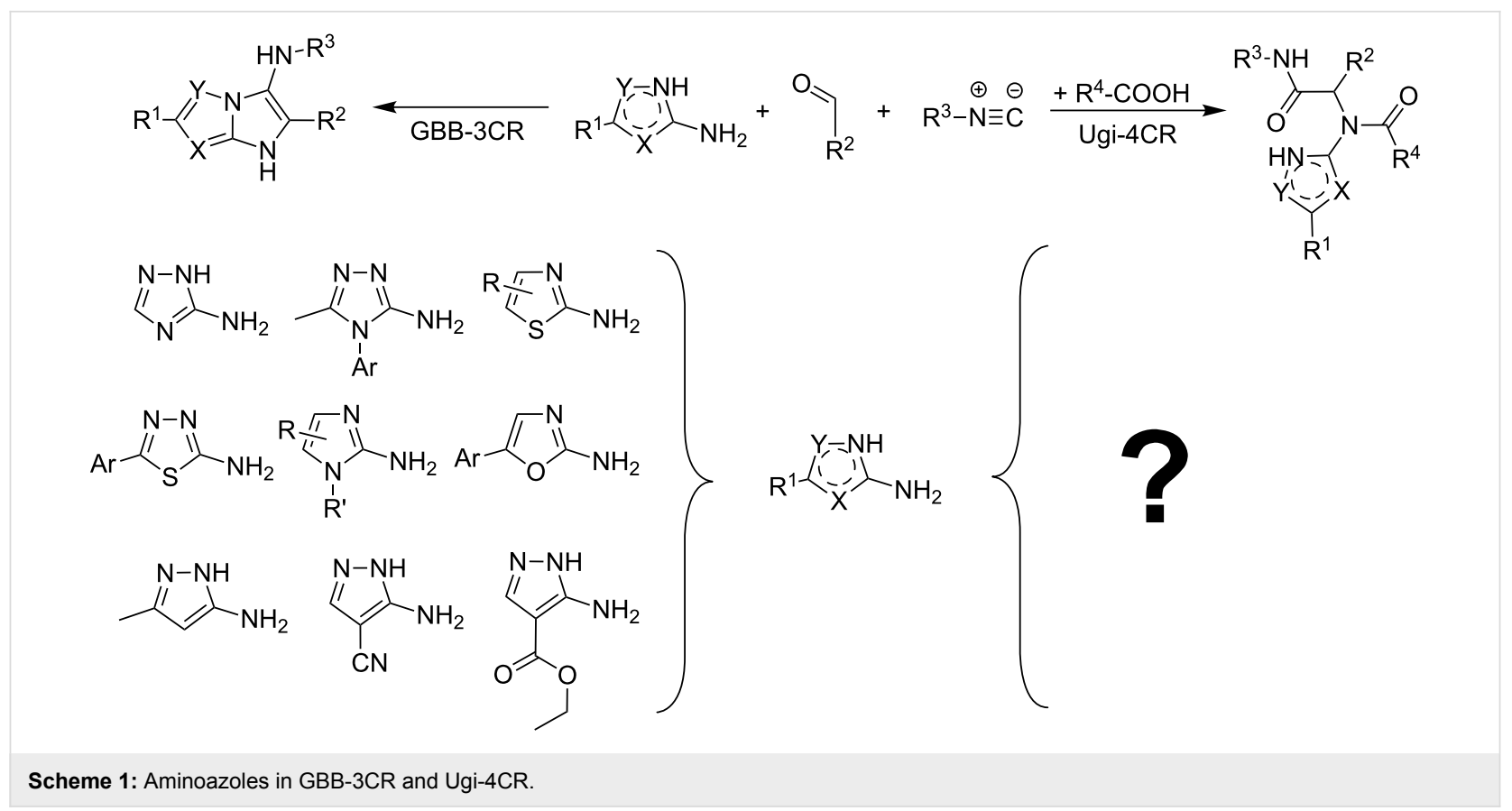


been studied yet, were examined as an amine component in Ugi-4CR and GBB-3CR. The generated compounds were screened for their biological activity towards Bacillus subtilis, Staphylococcus aureus, Escherichia coli and Pseudomonas aeruginosa.

\section{Results and Discussion}

Since aminoazoles contain an exocyclic $\mathrm{NH}_{2}$ group and an endocyclic nucleophilic center, they can act both as primary amines and as 1,3-binucleophiles, therefore, their treatments with isocyanides, aldehydes and carboxylic acids may proceed either as Ugi-4CR (aminoazole - primary amine, acid - reagent) or as GBB-3CR (aminoazole - 1,3-binucleophile, acid - catalyst). Literature data indicate $[14,25,59,97-101]$ that 5-aminopyrazoles bearing in the fourth position electron-withdrawing substituents like carboxamide, carboxylate or a carbonitrile group, posses chemical properties being different from other 5-aminopyrazoles but sometimes similar to 3-amino-1,2,4-triazole that was described as a component of GBB-3CR earlier [71-75]. Therefore, the first type of aminoazoles studied in our work was 5 -amino- $N$-aryl- $1 H$-pyrazole-4-carboxamide that showed 1,3-binucleophile properties in the condensation with aromatic aldehydes and alkylisocyanides giving the product resulting from GBB-3CR. On the other hand, 3-amino-5methylisoxazole in MCRs often acted as primary amine [102106], that was confirmed in our case by treatment with aromatic aldehydes, alkylisocyanides and phenylpropiolic acid resulting in the corresponding products of the Ugi-4CR (Scheme 2).

The scope and limitations of isocyanide-based reactions involving 5-amino- $N$-aryl-1 $H$-pyrazole-4-carboxamides and 3-amino5-methylisoxazole were studied in detail. It was established that the optimal reaction conditions of a GBB-3CR involving 5-amino- $\mathrm{N}$-aryl- $1 \mathrm{H}$-pyrazole-4-carboxamides $\mathbf{2 a - d}$ were different depending on the other substrates. Particularly, the condensation involving tert-butylisocyanide (3a) and aldehydes 1a-e bearing electron-donating substituents was effectively carried out in $\mathrm{EtOH} / \mathrm{H}_{2} \mathrm{O}$ mixture with TFA $(10 \mathrm{~mol} \%)$ at room temperature for $24 \mathrm{~h}$ (method A) resulting in the formation of imidazopyrazoles 4a-m (Table 1, entries 1-13).

This condensation was also carried out in TFE or $\mathrm{MeOH}$ with addition of $\mathrm{HClO}_{4}(10 \mathrm{~mol} \%)$, but a significant amount of Schiff base 5 (Table 1) was observed in this case. The reaction involving aldehydes $\mathbf{1 f}-\mathbf{h}$ bearing strong electron-withdrawing groups under all the abovementioned conditions allowed isolating a mixture of imidazopyrazoles $\mathbf{4 n}-\mathbf{v}$ with a large quantity of Schiff bases $\mathbf{5}$.

Therefore, the conditions for the synthesis of compounds $\mathbf{4 n}-\mathbf{v}$ were optimized employing 5-amino- $N$-(3-fluorophenyl)- $1 H$ pyrazole-4-carboxamide (2b), methyl benzaldehyde-4-carboxylate (1f) and tert-butylisocyanide (3a, Table 2).

Obviously, this reaction requires a longer reaction time (min. $48 \mathrm{~h}$ ) and a moderate temperature (not more than $85^{\circ} \mathrm{C}$ ) to avoid tarring. Thus, after $48 \mathrm{~h}$ of heating (oil bath) at $85^{\circ} \mathrm{C}$ the starting materials $\mathbf{1 f}, \mathbf{2 b}$ and $\mathbf{3 a}$ in EtOH/ $\mathrm{H}_{2} \mathrm{O}$ with TFA (10 mol \%), imidazopyrazole $4 \mathrm{q}$ was isolated in $56 \%$ yield. However, the mother liquor still contained unreacted Shiff base $\mathbf{5 q}$ (entry 7, Table 2 ). On the other hand, using $\mathrm{DMF} / \mathrm{HClO}_{4}$ (10 mol \%, method B) allowed obtaining the target compound $\mathbf{4 q}$ in $88 \%$ yield with no impurities (entry 9 , Table 2 ).

Similarly the reaction of 5-amino- $N$-(4-fluorophenyl)- $1 H$-pyrazole-4-carboxamide (2a) with 4-nitrobenzaldehyde (1g) and tert-butylisocyanide (3a) in EtOH $/ \mathrm{H}_{2} \mathrm{O}$ with TFA (10 mol \%) also led to Shiff base $\mathbf{5 0}$ while stirring the starting materials in DMF- $-\mathrm{HClO}_{4}(10 \mathrm{~mol} \%)$ for $48 \mathrm{~h}$ gave compound 40 (Table 3).

It should be noted that the conditions of method $\mathrm{B}$ are also suitable for obtaining imidazopyrazoles $\mathbf{4 a}-\mathbf{m}$ in comparatively high yields; however, the synthesis in $\mathrm{EtOH} / \mathrm{H}_{2} \mathrm{O}$ medium is preferred from the point of view of green chemistry. Thereby,

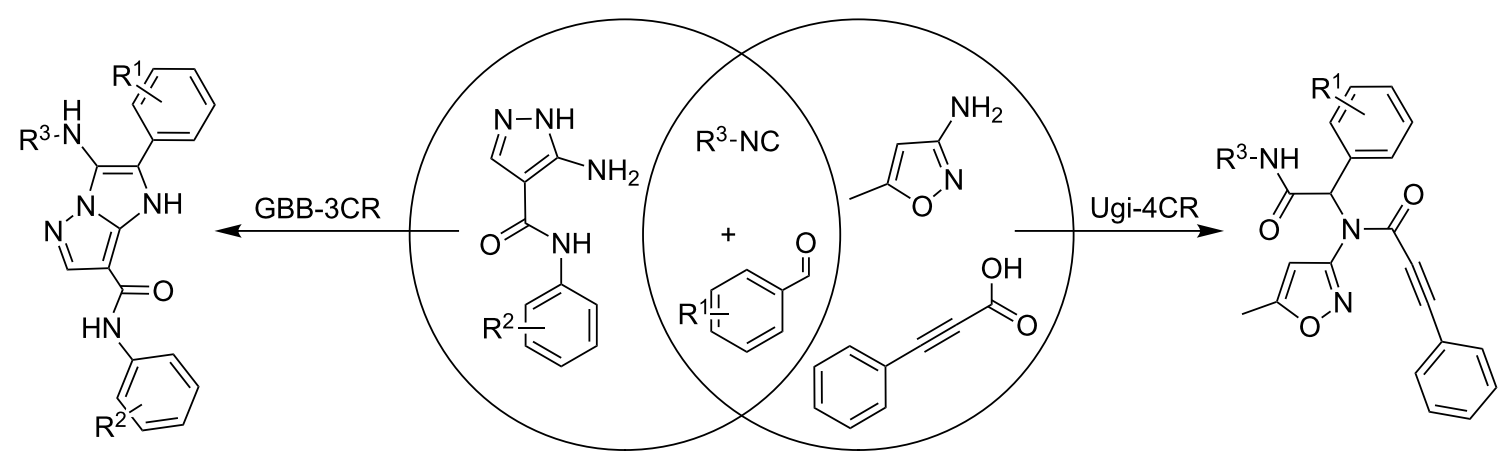

Scheme 2: Reactivity of 5-amino- $\mathrm{N}$-aryl-1H-pyrazole-4-carboxamide and 3-amino-5-methylisoxazole in GBB-3CR and Ugi-4CR. 
Table 1: CBB-3CR involving tert-butylisocyanide.<smiles>[R]c1cccc(NC(=O)c2cn[nH]c2N)c1</smiles>

4a-m: method A ( $\left.\mathrm{H}_{2} \mathrm{O} / \mathrm{EtOH}(1: 1), \operatorname{TFA}(10 \mathrm{~mol} \%), \mathrm{rt}, 24 \mathrm{~h}\right)$;

4n-v: method B (DMF, $\left.\mathrm{HClO}_{4}(10 \mathrm{~mol} \%), \mathrm{rt}, 48 \mathrm{~h}\right)$.

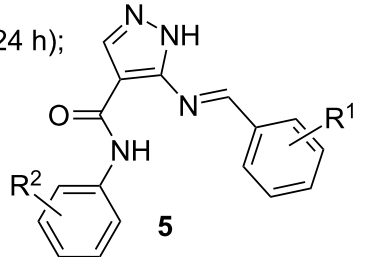

\begin{tabular}{|c|c|c|c|c|c|c|c|}
\hline \multirow[t]{2}{*}{ Entry } & \multicolumn{4}{|c|}{ Starting materials } & \multirow[t]{2}{*}{ Method } & \multirow[t]{2}{*}{ Product } & \multirow[t]{2}{*}{ Yield, \% } \\
\hline & Aldehydes & $\mathrm{R}^{1}$ & Aminopyrazoles & $\mathrm{R}^{2}$ & & & \\
\hline 1 & $1 a$ & $\mathrm{H}$ & $2 a$ & $4-\mathrm{F}$ & $A$ & $4 a$ & 54 \\
\hline 2 & $1 b$ & $2-\mathrm{CH}_{3} \mathrm{O}$ & $2 a$ & $4-\mathrm{F}$ & $A$ & $4 b$ & 75 \\
\hline 3 & $1 c$ & $3-\mathrm{CH}_{3} \mathrm{O}$ & $2 a$ & $4-\mathrm{F}$ & $A$ & $4 c$ & 77 \\
\hline 4 & $1 d$ & $4-\mathrm{CH}_{3} \mathrm{O}$ & $2 a$ & $4-\mathrm{F}$ & $A$ & $4 d$ & 75 \\
\hline 5 & $1 e$ & $4-\mathrm{Cl}$ & $2 a$ & $4-\mathrm{F}$ & A & $4 e$ & 72 \\
\hline 6 & $1 b$ & $2-\mathrm{CH}_{3} \mathrm{O}$ & $2 b$ & $3-\mathrm{F}$ & $A$ & $4 f$ & 83 \\
\hline 7 & 1d & $4-\mathrm{CH}_{3} \mathrm{O}$ & $2 b$ & $3-\mathrm{F}$ & $A$ & $4 g$ & 64 \\
\hline 8 & $1 e$ & 4-Cl & $2 b$ & $3-\mathrm{F}$ & $A$ & $4 \mathrm{~h}$ & 89 \\
\hline 9 & $1 b$ & $2-\mathrm{CH}_{3} \mathrm{O}$ & 2c & $2-\mathrm{CH}_{2} \mathrm{CH}_{3}$ & $A$ & $4 i$ & 82 \\
\hline 10 & $1 d$ & $4-\mathrm{CH}_{3} \mathrm{O}$ & 2c & $2-\mathrm{CH}_{2} \mathrm{CH}_{3}$ & A & $4 j$ & 64 \\
\hline 11 & $1 e$ & $4-\mathrm{Cl}$ & $2 c$ & $2-\mathrm{CH}_{2} \mathrm{CH}_{3}$ & $A$ & $4 k$ & 66 \\
\hline 12 & $1 b$ & $2-\mathrm{CH}_{3} \mathrm{O}$ & $2 d$ & $4-\mathrm{CH}_{2} \mathrm{CH}_{3}$ & A & $4 I$ & 85 \\
\hline 13 & $1 e$ & $4-\mathrm{Cl}$ & $2 d$ & $4-\mathrm{CH}_{2} \mathrm{CH}_{3}$ & A & $4 m$ & 53 \\
\hline 14 & $1 f$ & $4-\mathrm{CO}_{2} \mathrm{CH}_{3}$ & $2 a$ & $4-\mathrm{F}$ & B & $4 n$ & 85 \\
\hline 15 & $1 \mathrm{~g}$ & $4-\mathrm{NO}_{2}$ & $2 a$ & $4-\mathrm{F}$ & B & 40 & 87 \\
\hline 16 & $1 \mathrm{~h}$ & $4-\mathrm{CN}$ & $2 a$ & $4-\mathrm{F}$ & B & $4 p$ & 90 \\
\hline 17 & $1 f$ & $4-\mathrm{CO}_{2} \mathrm{CH}_{3}$ & $2 b$ & $3-\mathrm{F}$ & B & $4 q$ & 88 \\
\hline 18 & $1 \mathrm{~g}$ & $4-\mathrm{NO}_{2}$ & $2 b$ & $3-\mathrm{F}$ & B & $4 r$ & 87 \\
\hline 19 & $1 \mathrm{~h}$ & $4-\mathrm{CN}$ & $2 b$ & $3-\mathrm{F}$ & B & $4 s$ & 82 \\
\hline 20 & $1 f$ & $4-\mathrm{CO}_{2} \mathrm{CH}_{3}$ & $2 c$ & $2-\mathrm{CH}_{2} \mathrm{CH}_{3}$ & B & $4 t$ & 61 \\
\hline 21 & $1 \mathrm{~g}$ & $4-\mathrm{NO}_{2}$ & $2 c$ & $2-\mathrm{CH}_{2} \mathrm{CH}_{3}$ & B & $4 u$ & 79 \\
\hline 22 & $1 \mathrm{~h}$ & $4-\mathrm{CN}$ & $2 c$ & $2-\mathrm{CH}_{2} \mathrm{CH}_{3}$ & B & $4 v$ & 83 \\
\hline
\end{tabular}

the optimal methodology for obtaining compounds $\mathbf{4 a}-\mathbf{m}$ is the synthesis according to the method $\mathrm{A}\left(\mathrm{H}_{2} \mathrm{O} / \mathrm{EtOH}(1: 1)\right.$, TFA (10 mol \%), rt, $24 \mathrm{~h}$ ) while for compounds $4 \mathbf{n}-\mathbf{v}$ method B (DMF, $\mathrm{HClO}_{4}(10 \mathrm{~mol} \%), \mathrm{rt}, 48 \mathrm{~h}$ ) proved to be superior (Table 1, entries 14-22).

We presume that such difference in the outcome of GBB-3CR depending on the substitution pattern in the carbonyl component is related with the ability of the intermediate Schiff bases to be protonated as well as with their solubility. In case of the presence of electron-withdrawing substituents in the aldehyde the corresponding Schiff bases $\mathbf{5}$ are less soluble and less basic. DMF increases solubility of imines $\mathbf{5}$, while the application of strong acid $\left(\mathrm{HClO}_{4}\right)$ promotes Shiff bases protonation.

Phenylpyruvic acid (1') was also applied as carbonyl component in GBB-3CR to obtain imidazopyrazoles having a carboxylic group. However, the process of decarboxylation took place in the reaction and 1- $H$-imidazopyrazole carboxamides $\mathbf{4 w}, \mathbf{x}$ were isolated as the sole reaction products (Table 4). 
Table 2: Optimization of the reaction conditions for the synthesis of compound $\mathbf{4 q}$.

\begin{tabular}{cccccc} 
Sield, \% & \\
\hline
\end{tabular}

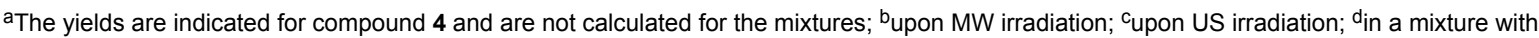
starting materials and undetected impurities.

Table 3: Optimization of the reaction conditions for the synthesis of compound $\mathbf{4 0}$.<smiles>CC(C)(C)Nc1c(-c2ccc([N+](=O)[O-])cc2)[nH]c2c(C(=O)Nc3ccc(F)cc3)cnn12</smiles>

\begin{tabular}{|c|c|c|c|c|c|}
\hline Entry & Solvent & Time, hours & $T,{ }^{\circ} \mathrm{C}$ & Main product & Yield, $(\%)^{a}$ \\
\hline 1 & $\mathrm{EtOH} / \mathrm{H}_{2} \mathrm{O}(1: 1), \mathrm{TFA},(10 \mathrm{~mol} \%)$ & 72 & 25 & $5^{b}$ & - \\
\hline 2 & $\mathrm{EtOH} / \mathrm{H}_{2} \mathrm{O}(1: 1), \mathrm{TFA},(10 \mathrm{~mol} \%)$ & 2 & $140^{c}$ & $5^{\mathrm{b}}$ & - \\
\hline 3 & $\mathrm{EtOH} / \mathrm{H}_{2} \mathrm{O}(1: 1), \mathrm{TFA},(10 \mathrm{~mol} \%)$ & 72 & 90 & $5^{b}$ & - \\
\hline 4 & DMF, $\mathrm{HClO}_{4},(10 \mathrm{~mol} \%)$ & 48 & 25 & 4 & 87 \\
\hline
\end{tabular}

aThe yields are indicated for compound 40 ; ${ }^{\text {in }}$ a mixture with starting materials and undetected impurities; ${ }^{\mathrm{c}}$ upon $\mathrm{MW}$ irradiation.

When replacing tert-butylisocyanide (3a) with ethyl 2-isocyanoacetate $(\mathbf{3 b})$, imidazo[1,2-b]pyrazole-7-carboxamides $\mathbf{6 a}-\mathbf{h}$ were isolated. The condensation proceeded well in TFE with the addition of $\mathrm{HClO}_{4}(10 \mathrm{~mol} \%)$ upon stirring for $24 \mathrm{~h}$ (Table 5). On the other hand, condensation of the starting reagents $\mathbf{1 d}-\mathbf{g}$ with $\mathbf{2 a}, \mathbf{b}$ and $\mathbf{3 b}$ in $\mathrm{EtOH} / \mathrm{H}_{2} \mathrm{O}(1: 1)$ with TFA $(10 \mathrm{~mol} \%)$ resulted in the formation of the target products 6 in a mixture with a substantial amount of
Schiff bases $\mathbf{5}$. Moreover, only imines $\mathbf{5}$ with impurities of the starting compounds were isolated when applying DMF with $\mathrm{HClO}_{4}$.

Interestingly, in case of ethyl 2-isocyanoacetate $(\mathbf{3 b})$ the reaction proceeded equally well regardless of the substituent in the aldehyde. This can be connected with an increased reactivity of ethyl 2-isocyanoacetate (3b) compared to tert-butylisocyanide 
Table 4: Phenylpyruvic acid in GBB-3CR.

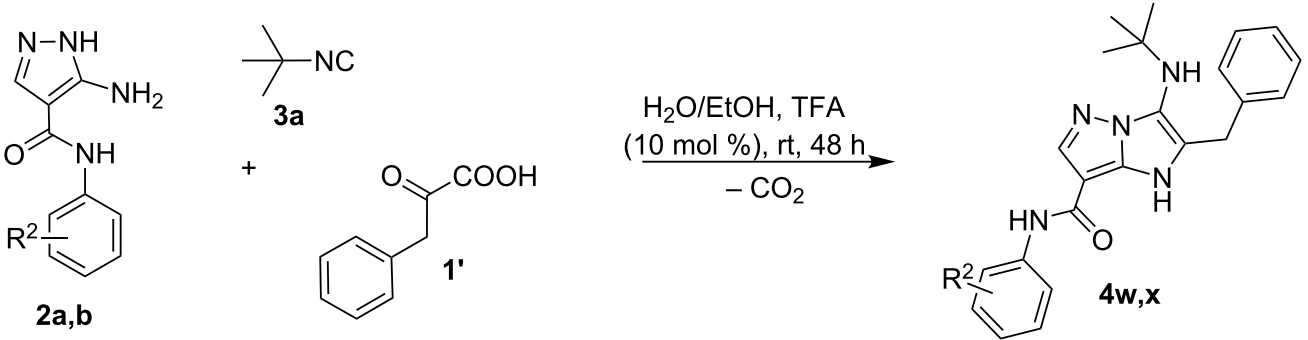

\begin{tabular}{ccccc}
\hline Entry & \multicolumn{2}{c}{$\begin{array}{c}\text { Starting materials } \\
\text { Aminopyrazoles }\end{array}$} & \multicolumn{2}{c}{ Product } \\
& Rield, \% & \\
\hline 1 & $\mathbf{2 a}$ & $4-\mathrm{F}$ & $\mathbf{4 w}$ & 48 \\
2 & $\mathbf{2 b}$ & $3-\mathrm{F}$ & $\mathbf{4 x}$ & 42
\end{tabular}

Table 5: GBB-3CR involving ethyl 2-isocyanoacetate.

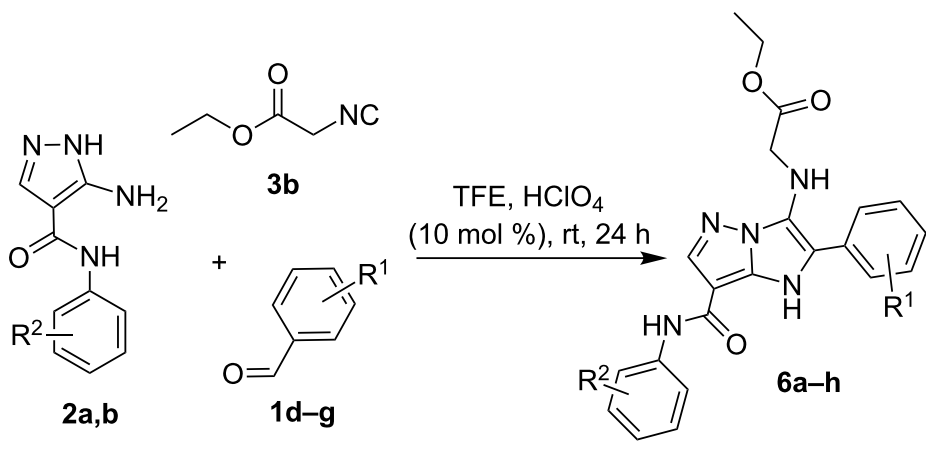

\begin{tabular}{|c|c|c|c|c|c|c|}
\hline \multirow[t]{2}{*}{ Entry } & \multicolumn{4}{|c|}{ Starting materials } & \multirow[t]{2}{*}{ Product } & \multirow[t]{2}{*}{ Yield, \% } \\
\hline & Aldehydes & $\mathrm{R}^{1}$ & Aminopyrazoles & $\mathrm{R}^{2}$ & & \\
\hline 1 & $1 d$ & 4- $\mathrm{CH}_{3} \mathrm{O}$ & $2 a$ & $4-\mathrm{F}$ & $6 a$ & 77 \\
\hline 2 & $1 \mathrm{e}$ & $4-\mathrm{Cl}$ & $2 a$ & $4-\mathrm{F}$ & $6 b$ & 95 \\
\hline 3 & $1 f$ & $4-\mathrm{CO}_{2} \mathrm{CH}_{3}$ & $2 a$ & $4-\mathrm{F}$ & $6 c$ & 67 \\
\hline 4 & $1 \mathrm{~g}$ & $4-\mathrm{NO}_{2}$ & $2 a$ & $4-\mathrm{F}$ & $6 d$ & 85 \\
\hline 5 & $1 d$ & $4-\mathrm{CH}_{3} \mathrm{O}$ & $2 b$ & $3-F$ & $6 e$ & 78 \\
\hline 6 & $1 e$ & $4-\mathrm{Cl}$ & $2 b$ & $3-\mathrm{F}$ & $6 f$ & 84 \\
\hline 7 & $1 f$ & $4-\mathrm{CO}_{2} \mathrm{CH}_{3}$ & $2 b$ & $3-F$ & $6 \mathrm{~g}$ & 82 \\
\hline 8 & $1 \mathrm{~g}$ & $4-\mathrm{NO}_{2}$ & $2 b$ & $3-F$ & $6 h$ & 80 \\
\hline
\end{tabular}

(3a) due to sterical reasons thus leveling the influence of the solubility factor of imines 5 .

As it has been already mentioned above, in contrast to 5-amino$\mathrm{N}$-aryl-1H-pyrazole-4-carboxamides 2, 3-amino-5-methylisoxazole (7) exhibited only properties of primary amines that allowed using it as an amine component in Ugi-4CR. Particularly, its reaction with aromatic aldehydes $\mathbf{1 a}-\mathbf{h}$, phenylpropiolic acid (8) and tert-butylisocyanide (3a) gave peptidomimetics 9 under stirring the starting reagents in $\mathrm{MeOH}$ at room temperature for $24 \mathrm{~h}$. In the presence of strong electron-withdrawing substituents as nitro or cyano groups in para-position of the aldehyde, despite the variation of the reaction conditions, only imines $\mathbf{1 0}$ were isolated as the major products. In case of 4-cyanobenzaldehyde (1h) we managed to isolate Ugi product $\mathbf{9 g}$ in a low yield of $18 \%$ (Table 6). 


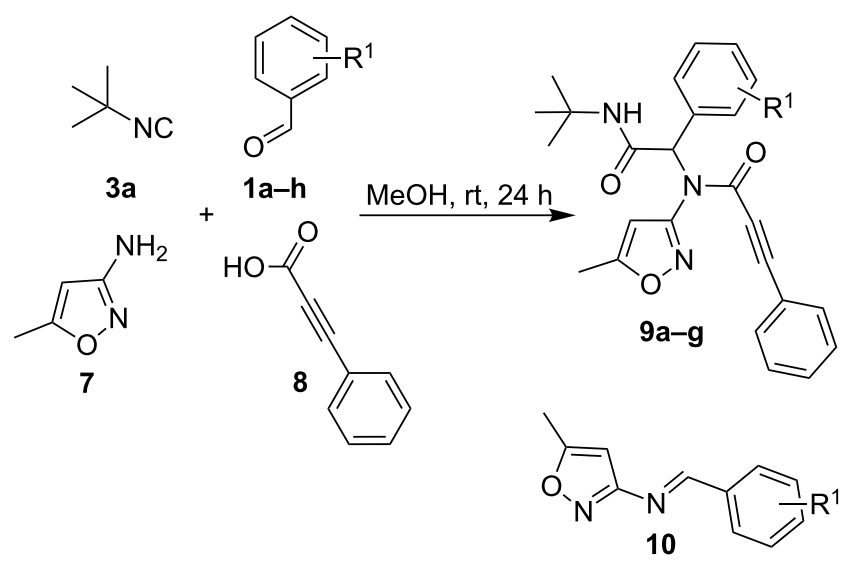

\begin{tabular}{|c|c|c|c|c|}
\hline \multirow[t]{2}{*}{ Entry } & \multicolumn{2}{|c|}{ Starting materials } & \multirow[t]{2}{*}{ Product } & \multirow[t]{2}{*}{ Yield $^{\mathrm{b}}, \%$} \\
\hline & Aldehydes & $\mathrm{R}^{1}$ & & \\
\hline 1 & $1 a$ & $\mathrm{H}$ & $9 a$ & 49 \\
\hline 2 & $1 b$ & $2-\mathrm{CH}_{3} \mathrm{O}$ & $9 b$ & 67 \\
\hline 3 & $1 c$ & $3-\mathrm{CH}_{3} \mathrm{O}$ & $9 c$ & 51 \\
\hline 4 & $1 d$ & $4-\mathrm{CH}_{3} \mathrm{O}$ & $9 d$ & 73 \\
\hline 5 & $1 e$ & $4-\mathrm{Cl}$ & $9 e$ & 43 \\
\hline 6 & $1 f$ & $4-\mathrm{CO}_{2} \mathrm{CH}_{3}$ & $9 f$ & 43 \\
\hline 7 & $1 \mathrm{~g}$ & $4-\mathrm{NO}_{2}$ & $10 \mathrm{~g}^{\mathrm{a}}$ & $-^{\mathrm{b}}$ \\
\hline 8 & $1 \mathrm{~h}$ & $4-\mathrm{CN}$ & $9 \mathrm{~h}$ & 18 \\
\hline
\end{tabular}

ag was not isolated; bthe yields are indicated for compounds $\mathbf{9}$.

It should be noted that 5 -amino- $N$-aryl- $1 H$-pyrazole-4-carboxamides 2 were also introduced into Ugi-4CR with aromatic aldehydes 1, alkylisocyanides $\mathbf{3}$ and phenylpropiolic acid $\mathbf{8}$; however, the acid $\mathbf{8}$ acted as a catalyst favouring the formation of GBB-3CR-products 4. The attempts to carry out GBB-3CR involving 3-amino-5-methylisoxazole (7) according to the elaborated procedures (Table 1, methods A or B) as well as under other conditions were not successful.

\section{Structure elucidation}

The purity and structures of the heterocycles obtained were established by means of mass spectrometry (including HRMS), NMR spectroscopy and X-ray diffraction study.

The ${ }^{1} \mathrm{H}$ NMR spectra of imidazo[1,2- $\left.b\right]$ pyrazole-7-carboxamides 4 exhibit a broad signal for the NH group in the position 1 at ca. $11.8 \mathrm{ppm}$, a broad signal for the carboxamide $\mathrm{NH}$ at $\approx 9.5 \mathrm{ppm}$, a singlet for pyrazole $\mathrm{CH}$ in the position 6 at $\approx 8.2 \mathrm{ppm}$, a broad signal for the NH group near the position 3 at $\approx 5.1 \mathrm{ppm}$, a singlet for tert-butyl $\mathrm{CH}_{3}$ groups at $\approx 1.0 \mathrm{ppm}$, resonances for the aromatic protons around 6.9-8.2 ppm as well as signals for other substituents. In case of imidazo[1,2- $b]$ pyrazole-7-carboxamides $\mathbf{4 w}, \mathbf{x}$ a broad signal for the tert-butyl $\mathrm{NH}$ group is shifted upfield to $4.2 \mathrm{ppm}$ and an additional singlet for the benzyl $\mathrm{CH}_{2}$ group is present at $3.9 \mathrm{ppm}$.

The ${ }^{1} \mathrm{H}$ NMR spectra of imidazo[1,2-b]pyrazole-7-carboxamides 6 exhibit a broad signal for the NH group in the position 1 at $\approx 11.8 \mathrm{ppm}$, a broad signal for the carboxamide $\mathrm{NH}$ group at $\approx 9.6 \mathrm{ppm}$, a singlet for the pyrazole $\mathrm{CH}$ in the position 6 at $\approx 8.2 \mathrm{ppm}$, a broad signal for the $\mathrm{NH}$ group near the position 3 at $\approx 5.7 \mathrm{ppm}$, a singlet for the $\mathrm{CH}_{2}$ group in the acetate moiety at $\approx 4.2 \mathrm{ppm}$, peaks for the ethoxy group: a quartet for $\mathrm{CH}_{2}$ group at $\approx 4.0 \mathrm{ppm}$ and a triplet for the $\mathrm{CH}_{3}$ group at $\approx 1.0 \mathrm{ppm}$, peaks for the aromatic protons around 6.7-7.7 ppm as well as signals for other substituents.

The ${ }^{1} \mathrm{H}$ NMR spectra of $N$-(1-arylethyl-2-(tert-butylamino)-2oxo)- $N$-(5-methylisoxazol-3-yl)-3-phenylpropiolamides 9 exhibit a broad signal for the amide NH group at $\approx 7.9 \mathrm{ppm}$, singlet for the isoxazole $\mathrm{CH}$ at $\approx 6.3 \mathrm{ppm}$, a singlet for the $\mathrm{CH}$ group in the position 1 at $\approx 6.0 \mathrm{ppm}$, a singlet for the isoxazole $\mathrm{CH}_{3}$ 
group at $\approx 2.3 \mathrm{ppm}$, a singlet for the tert-butyl $\mathrm{CH}_{3}$ groups at $\approx 1.2 \mathrm{ppm}$, peaks for the aromatic protons around $6.8-7.5 \mathrm{ppm}$ as well as signals for other substituents.

As it was found earlier for 2-aminopyrimidines [107-109] GBB$3 \mathrm{CR}$ may lead to the formation of two positional isomers $\mathbf{A}$ and B (Figure 1).<smiles>[R]c1ccccc1NC(=O)c1cnn2c(N[AlH])c(-c3ccccc3[R])[nH]c12</smiles><smiles>[R]c1cccc(-c2c(N[AlH2])[nH]c3c(C(=O)Nc4ccccc4)cnn23)c1</smiles>

Figure 1: Alternative structures $\mathbf{A}$ and $\mathbf{B}$ for compounds 4 and 6 .

Experiment with $\mathrm{D}_{2} \mathrm{O}$ allowed to identify the signals of $\mathrm{NH}$ protons while the HSQC spectrum showed the correlations between the signals of protons and corresponding carbon atoms (in the position 6 and in tert-butyl group). The correlations between the signals of $\mathrm{NH}$ protons and corresponding carbon atoms (through two and three bonds, Figure 2) allowed final distinguishing the shifts of three $\mathrm{NH}$ groups signals in ${ }^{1} \mathrm{H}$ NMR spectra.
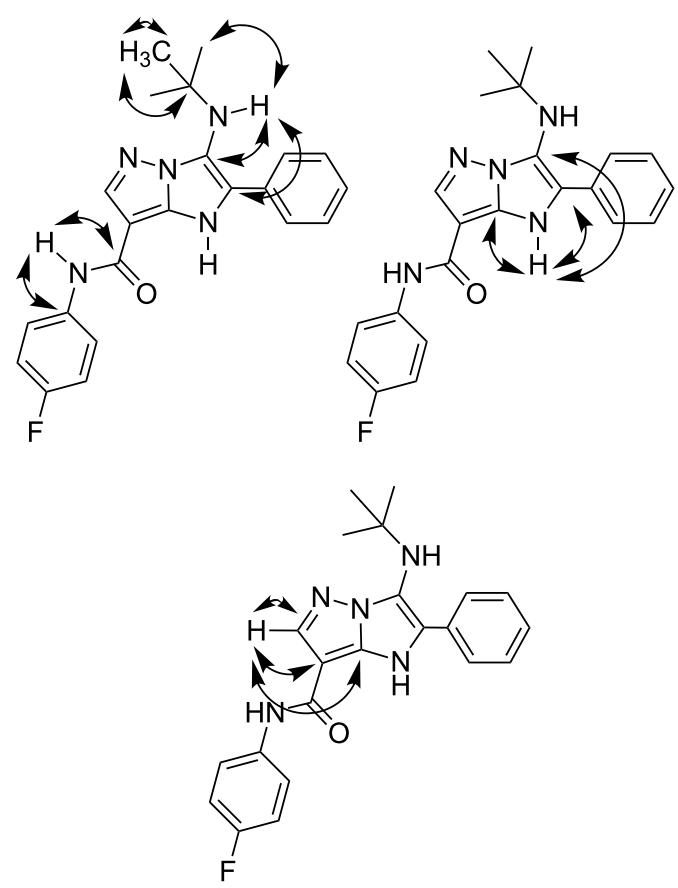

Figure 2: Selected data of HSQC and HMBC experiments for compound 4 a.
However, the final assignment of the structure A for heterocycles 4 was made with the help of X-ray analysis (Figure 3).

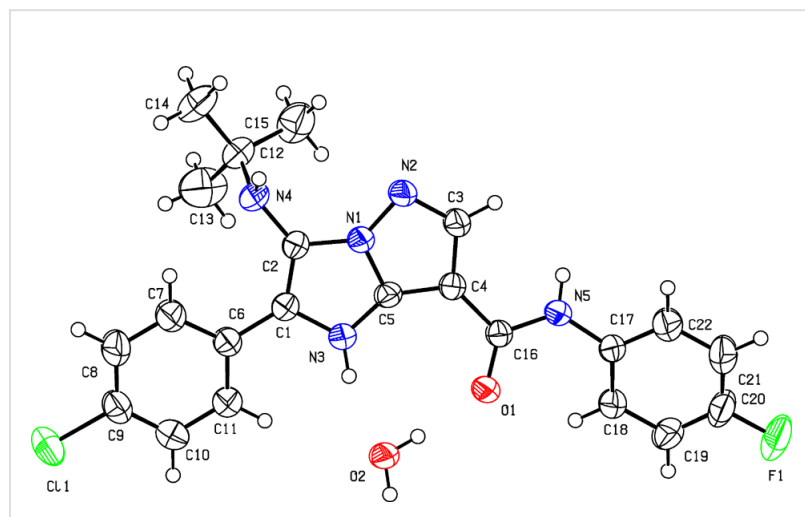

Figure 3: Molecular structure of 3-(tert-butylamino)-2-(4-chlorophenyl)$\mathrm{N}$-(4-fluorophenyl)-1H-imidazo[1,2-b]pyrazole-7-carboxamide (4e) (X-ray diffraction data). Non-hydrogen atoms are presented as thermal ellipsoids with $50 \%$ probability.

In the case of compounds 9 the presence of NOE between the signals of the methyl group and the $\mathrm{CH}$ group in the isoxazole moiety allowed to distinguish closely located signals of two $\mathrm{CH}$ groups (Figure 4).

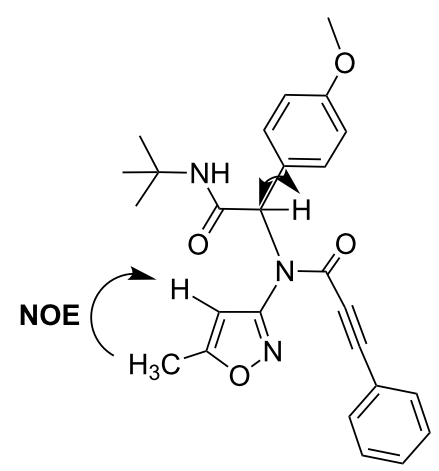

Figure 4: Selected data of NOE and HSQC experiments for compound 9d.

Ultimately, the structure of compounds 9 was proven by an X-ray analysis of compound 9e (Figure 5).

\section{Antibacterial activity}

The antibacterial activity of compounds $\mathbf{4 ,} 6$ and 9 (Table 7) was studied (see Experimental part in Supporting Information File 1 for details) against reference bacterial cultures: Bacillus subtilis (strain 1211), Staphylococcus aureus (strain 2231) (Gram-positive) and Escherichia coli (strain 1257), Pseudomonas aeruginosa (strain 1111) (Gram-negative). 


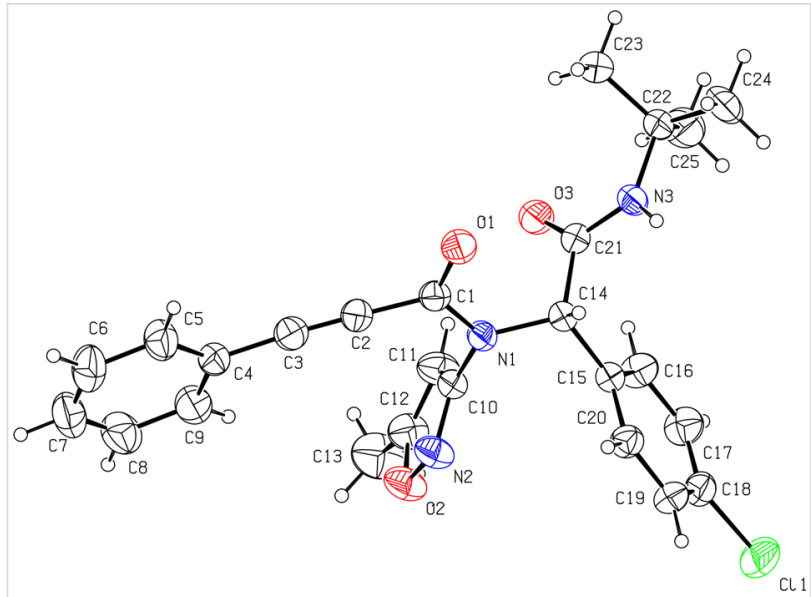

Figure 5: Molecular structure of $\mathrm{N}$-(2-(tert-butylamino)-1-(4-chlorophenyl)-2-oxoethyl)-N-(5-methylisoxazol-3-yl)-3-phenylpropiolamide (9e) (X-ray diffraction data). Non-hydrogen atoms are presented as thermal ellipsoids with $50 \%$ probability.
As it follows from the results obtained several of the substances studied inhibit the growth of test-microorganisms demonstrating a weak antimicrobial effect (Table 7). Generally, the compounds were found to be less active than nitroxoline (being the reference substance).

The antimicrobial effect of the heterocycles studied is different depending on each bacterical strain; however, some rules can be seen. Only a few substances inhibited the growth of Gram-negative bacteria (strains of E. coli and P. aeruginosa) in an effective way. Particularly, compounds $\mathbf{4 a}$ and $\mathbf{6 g}$ inhibited the growth of $E$. coli in concentration $125 \mathrm{mg} / \mathrm{L}$. The bacteriostatic activity against $P$. aeruginosa of compounds $4 \mathbf{v}$ and $6 \mathbf{e}$ was fixed only in the highest concentration $500 \mathrm{mg} / \mathrm{L}$. The Grampositive bacterium $S$. aureus showed the resistance to almost all the compounds tested in the given concentration range. The strain of $B$. subtilis was found to be sensitive to compounds $4 \mathbf{i}$

Table 7: Antibacterial activity results.

Entry Substance $\quad \mathrm{MIC}^{\mathrm{a}} / \mathrm{MBC}^{\mathrm{b}}$,

$\mathrm{mg} / \mathrm{L}$
Strains of test cultures

Escherichia

Pseudomonas
aeruginosa

Staphylococcus aureus

Bacillus subtilis

125

MIC

MIC

$\mathrm{MBC}$

MIC

$\mathrm{MBC}$

MIC

$\mathrm{MBC}$

MIC

$M B C$

MIC

$M B C$

MIC

$\mathrm{MBC}$

MIC

$\mathrm{MBC}$

MIC

MBC

MIC

MBC

MIC

$\mathrm{MBC}$

MIC

$\mathrm{MBC}$

MIC

MBC

MIC

MBC

125

$-$

500

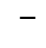

$-$

$-$

-

500

$-$

$-$

$-$

$-$

$-$

500

$-$

250

$-$

$-$

$-$

$-$

$-$

$-$

500

500

$-$

-

-

$\begin{array}{ll}- & - \\ - & -\end{array}$

- $\quad-$

-

-

-

-

- $\quad-$


Table 7: Antibacterial activity results. (continued)

\begin{tabular}{|c|c|c|c|c|c|c|}
\hline \multirow{2}{*}{15} & \multirow{2}{*}{$4 r$} & MIC & 250 & - & - & - \\
\hline & & MBC & - & - & - & - \\
\hline \multirow{2}{*}{16} & \multirow{2}{*}{$4 s$} & MIC & 500 & - & - & $-^{*}$ \\
\hline & & MBC & - & - & - & - \\
\hline \multirow{2}{*}{17} & \multirow{2}{*}{$4 t$} & MIC & - & - & - & $-^{*}$ \\
\hline & & $\mathrm{MBC}$ & - & - & - & - \\
\hline \multirow{2}{*}{18} & \multirow{2}{*}{$4 u$} & MIC & - & - & - & - \\
\hline & & MBC & - & - & - & - \\
\hline \multirow{2}{*}{19} & \multirow{2}{*}{$4 v$} & MIC & 500 & 500 & - & - \\
\hline & & MBC & - & - & - & - \\
\hline \multirow{2}{*}{20} & \multirow{2}{*}{$4 w$} & MIC & - & - & - & - \\
\hline & & MBC & - & - & - & - \\
\hline \multirow{2}{*}{21} & \multirow{2}{*}{$4 x$} & MIC & - & - & - & - \\
\hline & & $\mathrm{MBC}$ & - & - & - & - \\
\hline \multirow{2}{*}{22} & \multirow{2}{*}{$6 a$} & MIC & 500 & - & - & $-{ }^{*}$ \\
\hline & & $\mathrm{MBC}$ & - & - & - & - \\
\hline \multirow{2}{*}{23} & \multirow{2}{*}{$6 b$} & MIC & - & - & - & - \\
\hline & & $\mathrm{MBC}$ & - & - & - & - \\
\hline \multirow{2}{*}{24} & \multirow{2}{*}{$6 c$} & MIC & 500 & - & - & - \\
\hline & & MBC & - & - & - & - \\
\hline \multirow{2}{*}{25} & \multirow{2}{*}{$6 d$} & MIC & - & - & - & 500 \\
\hline & & MBC & - & - & - & - \\
\hline \multirow{2}{*}{26} & \multirow{2}{*}{$6 e$} & MIC & - & 500 & - & - \\
\hline & & MBC & - & - & - & - \\
\hline & & MIC & 500 & - & - & - \\
\hline 21 & $6 t$ & MBC & - & - & - & - \\
\hline 28 & & MIC & 125 & - & - & - \\
\hline 28 & $6 \mathbf{g}$ & MBC & - & - & - & - \\
\hline & & MIC & 500 & - & 500 & - \\
\hline 29 & $6 \mathrm{~h}$ & MBC & - & - & - & - \\
\hline & & MIC & - & - & - & - \\
\hline 30 & $9 a$ & MBC & - & - & - & - \\
\hline & & MIC & - & - & - & $-^{*}$ \\
\hline 31 & $9 b$ & MBC & - & - & - & - \\
\hline & & MIC & - & - & - & $-^{*}$ \\
\hline 32 & $9 c$ & MBC & - & - & - & - \\
\hline & & MIC & - & - & - & $-^{*}$ \\
\hline 33 & $9 d$ & MBC & - & - & - & - \\
\hline & & MIC & - & - & - & - \\
\hline 34 & $9 e$ & MBC & - & - & - & - \\
\hline & & MIC & - & - & - & $-^{*}$ \\
\hline 35 & $9 t$ & MBC & - & - & - & - \\
\hline & & MIC & 15.6 & 62.5 & 31.25 & 1.9 \\
\hline 36 & Nitroxoline & MBC & 15.6 & 62.5 & 31.25 & 1.9 \\
\hline
\end{tabular}

${ }^{\mathrm{a}} \mathrm{MIC}$ - minimum inhibitory concentration; ${ }^{\mathrm{b}} \mathrm{MBC}$ - minimum bactericidal concentration; ${ }^{\mathrm{C}}$ the substance in concentration $\leq 500 \mathrm{mg} / \mathrm{L}$ does not inhibit the culture growth; ${ }^{d}$ increase in biomass compared to control.

and $\mathbf{6 d}$, but the bacteriostatic activity was fixed only in the highest concentration $500 \mathrm{mg} / \mathrm{L}$. The information about the influence of the compounds on bacteria is important from the point of view of choosing the further strategy for the investiga- tions of their biological action. An absence or a low level of antibacterial activity of the heterocycles synthesized is a good prerequisite for carrying out the research on the other promising types of activity, e.g., anticancer, antidiabetic, etc., because 
in this case a negative influence on a microflora of the organism is decreased [110].

The other interesting feature of most of the compounds was the $30-50 \%$ increase in biomass of Gram-positive strains (mainly B. subtilis) compared to control. As it follows from a brief literature overview there are a lot of applications of metabolites (recombinant insulin [111], polyhydroxyalkanoates [112,113] etc. [114-119]) produced by the strains studied. Therefore, the found probiotic effect of the heterocycles has a very promising area for the further application while scaling up the production of biomass with the aim of shortening the time and saving resources [120,121]. Although this is a subject for a future detailed study the results of antibacterial activity allowed outlining the positive tendency.

\section{Conclusion}

In summary, the behavior of 5-amino- $N$-aryl- $1 H$-pyrazole-4carboxamide and 3-amino-5-methylisoxazole as an amine component in isocyanide-based multicomponent reactions was studied. Particularly, 5-amino- $N$-aryl- $1 H$-pyrazole-4-carboxamide reacted as 1,3-binucleophile with aromatic aldehydes and alkylisocyanides with the formation of 3-(alkylamino)- $N, 2-$ diaryl-1H-imidazo[1,2-b]pyrazole-7-carboxamides (Groebke-Blackburn-Bienaymé reaction). In contrast, 3-amino5-methylisoxazole acted as a primary amine in Ugi four-component reaction with aromatic aldehydes, phenylpropiolic acid and tert-butylisocyanide giving $\mathrm{N}$-(1-arylethyl-2-(tert-butylamino)2-oxo)- $N$-(5-methylisoxazol-3-yl)-3-phenylpropiolamides.

The optimal reaction conditions were different depending on the substituent in the carbonyl component and the structure of the isocyanide. Thus, GBB-3CR involving tert-butylisocyanide in the case of aldehydes with electron-donating substituents was carried out in an EtOH/ $\mathrm{H}_{2} \mathrm{O}$ mixture with TFA $(10 \mathrm{~mol} \%)$ at $\mathrm{rt}$ for $24 \mathrm{~h}$ and in $\mathrm{DMF} / \mathrm{HClO}_{4}(10 \mathrm{~mol} \%)$ at $\mathrm{rt}$ for $48 \mathrm{~h}$ in case of electron-withdrawing groups. When replacing tert-butylisocyanide with ethyl 2-isocyanoacetate the similar imidazo[1,2b]pyrazole-7-carboxamides were isolated from the treatment in $\mathrm{TFE} / \mathrm{HClO}_{4}(10 \mathrm{~mol} \%)$ at $\mathrm{rt}$ for $24 \mathrm{~h}$. Ugi-4CR involving tert-butylisocyanide proceeded under standard conditions in $\mathrm{MeOH}$

The broad antibacterial activity of the obtained compounds was studied as well. Several of the substances inhibited the growth of test microorganisms demonstrating a weak antimicrobial effect. For most of the stuctures a $30-50 \%$ increase in biomass of Gram-positive strains (mainly B. subtilis) compared to control was observed. After a detailed study this effect may be used to stimulate the growth of producers of biologically active compounds.

\section{Supporting Information}

\section{Supporting Information File 1}

Experimental and analytical data.

[http://www.beilstein-journals.org/bjoc/content/

supplementary/1860-5397-13-104-S1.pdf]

\section{Supporting Information File 2}

NMR spectra.

[http://www.beilstein-journals.org/bjoc/content/

supplementary/1860-5397-13-104-S2.pdf]

\section{Acknowledgements}

V. Chebanov was supported by a scholarship of KU Leuven (SF/14/006). M. Murlykina was supported by an Erasmus Mundus scholarship. We thank K. Duerinckx and D. Sysoiev for recording some ${ }^{1} \mathrm{H}$ NMR and ${ }^{13} \mathrm{C}$ NMR spectra, B. Demarsin and D. Sysoiev for measuring HRMS and LC-MC spectra, N. Gorobets and D. Sysoiev for the help with discussing the results.

\section{References}

1. Navigating the threat of antimicrobial resistance. In Pharmacol. Matters; Gavins, F., Ed.; 2014; Vol. 7 (3), pp 1-26.

2. Nordberg, P.; Monnet, L. D.; Cars, O. "A Public Health Approach to Innovation.". WHO project: Priority Medicines for Europe and the World; 2005; pp 1-40.

3. Coates, A.; Hu, Y.; Bax, R.; Page, C. Nat. Rev. Drug Discovery 2002, 1, 895-910. doi:10.1038/nrd940

4. Carlet, J.; Jarlier, V.; Harbarth, S.; Voss, A.; Goossens, H.; Pittet, D. Antimicrob. Resist. Infect. Control 2012, 1, No. 11. doi:10.1186/2047-2994-1-11

5. Scott, M. G.; Davidson, D. J.; Gold, M. R.; Bowdish, D.; Hancock, R. E. W. J. J. Immunol. 2002, 169, 3883-3891. doi:10.4049/jimmunol.169.7.3883

6. Ruijter, E.; Scheffelaar, R.; Orru, R. V. A. Angew. Chem., Int. Ed. 2011, 50, 6234-6246. doi:10.1002/anie.201006515

7. Marcaurelle, L. A.; Foley, M. A. Curr. Opin. Chem. Biol. 2010, 14, 285-288. doi:10.1016/j.cbpa.2010.05.001

8. Biggs-Houck, J. E.; Younai, A.; Shaw, J. T. Curr. Opin. Chem. Biol. 2010, 14, 371-382. doi:10.1016/j.cbpa.2010.03.003

9. Ganem, B. Acc. Chem. Res. 2009, 42, 463-472. doi:10.1021/ar800214s

10. Sunderhaus, J. D.; Martin, S. F. Chem. - Eur. J. 2009, 15, 1300-1308. doi:10.1002/chem.200802140

11. Touré, B. B.; Hall, D. G. Chem. Rev. 2009, 109, 4439-4486. doi:10.1021/cr800296p

12. Isambert, N.; Lavilla, R. Chem. - Eur. J. 2008, 14, 8444-8454. doi:10.1002/chem.200800473

13. Mironov, M. A. QSAR Comb. Sci. 2006, 25, 423-431. doi:10.1002/qsar.200540190

14. Chebanov, V. A.; Desenko, S. M. Diversity-Oriented Synth.; 2014; Vol. 1, pp 43-63. doi:10.2478/dos-2014-0003 
15. Dömling, A.; Ugi, I. Angew. Chem., Int. Ed. 2000, 39, 3168-3210. doi:10.1002/1521-3773(20000915)39:18<3168::AID-ANIE3168>3.0.C O;2-U

16. Banfi, L.; Basso, A.; Riva, R. In Synthesis of Heterocycles via Multicomponent Reactions l; Orru, R. V. A.; Ruijter, E., Eds.; Springer-Verlag : Berlin Heidelberg, 2010; Vol. 23, pp 1-39. doi:10.1007/7081_2009_23

17. Zhu, J.; Wang, Q.; Wang, M.-X., Eds. Multicomponent reactions in organic chemistry; Wiley-VCH, 2015.

18. Bienaymé, H.; Hulme, C.; Oddon, G.; Schmitt, P. Chem. - Eur. J. 2000, 6, 3321-3329. doi:10.1002/1521-3765(20000915)6:18<3321::AID-CHEM3321>3.0.C O;2-A

19. Dolle, R. E.; Le Bourdonnec, B.; Goodman, A. J.; Morales, G. A.; Thomas, C. J.; Zhang, W. J. Comb. Chem. 2008, 10, 753-802. doi:10.1021/cc800119z

20. Zarganes-Tzitzikas, T.; Chandgude, A. L.; Dömling, A. Chem. Rec. 2015, 15, 981-996. doi:10.1002/tcr.201500201

21. Cioc, R. C.; Ruijter, E.; Orru, R. V. A. Green Chem. 2014, 16, 2958-2975. doi:10.1039/c4gc00013g

22. Shaaban, S.; Abdel-Wahab, B. F. Mol. Diversity 2016, 20, 233-254. doi:10.1007/s11030-015-9602-6

23. Váradi, A.; Palmer, T. C.; Dardashti, R. N.; Majumdar, S. Molecules 2016, 21, 19. doi:10.3390/molecules21010019

24. Sadjadi, S.; Nahavandi, F.; Heravi, M. J. Iran. Chem. Soc. 2015, 12, 1049-1052. doi:10.1007/s13738-014-0564-x

25. Chebanov, V. A.; Desenko, S. M.; Gurley, T. W. Azaheterocycles Based on a,b-Unsaturated Carbonyls; Springer-Verlag: Berlin Heidelberg, 2008.

26. Kaur, T.; Wadhwa, P.; Bagchi, S.; Sharma, A. Chem. Commun. 2016, 52, 6958-6976. doi:10.1039/C6CC01562J

27. Devi, N.; Rawal, R. K.; Singh, V. Tetrahedron 2015, 71, 183-232. doi:10.1016/j.tet.2014.10.032

28. Bruno, O.; Brullo, C.; Bondavalli, F.; Ranise, A.; Schenone, S.; Falzarano, M. S.; Varani, K.; Spisani, S. Bioorg. Med. Chem. Lett. 2007, 17, 3696-3701. doi:10.1016/j.bmcl.2007.04.036

29. Baviskar, A. T.; Madaan, C.; Preet, R.; Mohapatra, P.; Jain, V.; Agarwal, A.; Guchhait, S. K.; Kundu, C. N.; Banerjee, U. C.; Bharatam, P. V. J. Med. Chem. 2011, 54, 5013-5030. doi:10.1021/jm200235u

30. Maul, C.; Sundermann, B.; Hennies, H.; Schneider, J.; Gerlach, M. Tert-butyl-(7-methylimidazo[1,2-a]pyridin-3-yl)-amine-derivative. WO PCT Patent Application WO/2001/027109, April 19, 2001.

31. Starrett, J. E., Jr.; Montzka, T. A.; Crosswell, A. R.; Cavanagh, R. L. J. Med. Chem. 1989, 32, 2204-2210. doi:10.1021/jm00129a028

32. Palmer, A. M.; Chrismann, S.; Münch, G.; Brehm, C.; Zimmermann, P. J.; Buhr, W.; Senn-Bilfinger, J.; Feth, M. P.; Simon, W. A. Bioorg. Med. Chem. 2009, 17, 368-384. doi:10.1016/j.bmc.2008.10.055

33. Okubo, T.; Yoshikawa, R.; Chaki, S.; Okuyama, S.; Nakazato, A. Bioorg. Med. Chem. 2004, 12, 423-438. doi:10.1016/j.bmc.2003.10.050

34. Mizushige, K.; Ueda, T.; Yukiiri, K.; Suzuki, H. Cardiovasc. Drug Rev. 2002, 20, 163-174. doi:10.1111/j.1527-3466.2002.tb00085.x

35. Mori, H.; Tanaka, M.; Kayasuga, R.; Masuda, T.; Ochi, Y.; Yamada, H.; Kishikawa, K.; Ito, M.; Nakamura, T. Bone 2008, 43, 840-848. doi:10.1016/j.bone.2008.07.242

36. Tominaga, M.; Yang, Y.-H.; Nakagawa, K.; Ogawa, H. Carbostyrill compounds, compositions containing same and processes for preparing same. Eur. Pat. Appl. EP52016 (A1), May 19, 1981.
37. Gueiffier, A.; Mavel, S.; Lhassani, M.; Elhakmaoui, A.; Snoeck, R.; Andrei, G.; Chavignon, O.; Teulade, J.-C.; Witvrouw, M.; Balzarini, J.; De Clercq, E.; Chapat, J. P. J. Med. Chem. 1998, 41, 5108-5112. doi:10.1021/jm981051y

38. Defosse, G.; Le Ber, P.; Saarmets, A.; Wick, A. New bicyclic imidazole ketone derivs. FR Patent FR2699919 (A1), July 1, 1994.

39. Elleder, D.; Young, J. A. T.; Baiga, T. J.; Noel, J. P. Non-nucleoside reverse transcriptase inhibitors. WO PCT Pat. Appl. WO2009/061856, May 14, 2009.

40. Véron, J.-B.; Allouchi, H.; Enguehard-Gueiffier, C.; Snoeck, R.; Andrei, G.; De Clercq, E.; Gueiffier, A. Bioorg. Med. Chem. 2008, 16, 9536-9545. doi:10.1016/j.bmc.2008.09.027

41. Gudmundsson, K. S.; Johns, B. A. Bioorg. Med. Chem. Lett. 2007, 17, 2735-2739. doi:10.1016/j.bmcl.2007.02.079

42. Al-Tel, T. H.; Al-Qawasmeh, R. A.; Zaarour, R. Eur. J. Med. Chem. 2011, 46, 1874-1881. doi:10.1016/j.ejmech.2011.02.051

43. Terada, A.; Wachi, K.; Miyazawa, H.; lizuka, Y.; Hasegawa, K.; Tabata, K. Use of imidazopyrazole derivatives as analgesics and anti-inflammatory agents. U.S. Patent 5,232,939, Aug 3, 1993.

44. Frey, B.; Hufton, R.; Harding, M.; Draffan, A. G. Compounds for the treatment of HCV. WO PCT Pat. Appl. WO 2013/036994 A1, March 21, 2013.

45. Mascitti, V.; McClure, K. F.; Munchhof, M. J.; Robinson,, R. P Imidazo-pyrazoles as GPR119 inhibitors. WO PCT Pat. Appl. WO2011/061679, May 26, 2011.

46. Zhang, J.; Singh, R.; Goff, D.; Kinoshita, T. Small molecule inhibitors of spleen tyrosine kinase (SYK). U.S. Pat. Appl. 20100316649 A1, Dec 16, 2010.

47. Ennis, H. L.; Möller, L.; Wang, J. J.; Selawry, O. S. Biochem. Pharmacol. 1971, 20, 2639-2646. doi:10.1016/0006-2952(71)90173-0

48. Oku, T.; Kawai, Y.; Marusawa, H.; Yamazaki, H.; Abe, Y.; Tanaka, H. E. 3-(Heteroaryl)-pyrazololi[1,5-a]pyrimidines. U.S. Patent 5,356,897, Oct 18, 1994

49. Kuehnert, S.; Oberboersch, S.; Sundermann, C.; Haurand, M.; Jostock,, R.; Schiene, K.; Tzschentke, T.; Christoph, T.; Kaulartz, D. Substituted bicyclic imidazo-3-ylamin compounds. WO PCT Pat. Appl. WO2006/029980 A1, March 23, 2006.

50. Berset, C.; Audetat, S.; Tietz, J.; Gunde, T.; Barberis, A.; Schumacher, A.; Traxler, P. Protein kinase inhibitors. WO PCT Pat. Appl. WO2005/120513 A1, Dec 22, 2005.

51. Goldfarb, D. S. Method for altering the lifespan of eukaryotic organisms. U.S. Pat. Appl. 2009/0163545 A1, 2009.

52. Van Niel, M. B.; Miah, A. Substituted imidazo[1,2-a]pyridines and their use as agonists at GABA-A receptors for treating or preventing neurological or psychlatric disorders. UK Pat. Appl. GB2448808 (A), Oct 29, 2008.

53. Ugi, I. Angew. Chem., Int. Ed. Engl. 1982, 21, 810-819. doi:10.1002/anie.198208101

54. Basso, A.; Banfi, L.; Riva, R.; Guanti, G. J. Org. Chem. 2005, 70, 575-579. doi:10.1021/jo048389m

55. Domling, A. Chem. Rev. 2006, 106, 17-89. doi:10.1021/cr0505728

56. Hulme, C.; Gore, V. Curr. Med. Chem. 2003, 10, 51-80. doi:10.2174/0929867033368600

57. Akritopoulou-Zanze, I. Curr. Opin. Chem. Biol. 2008, 12, 324-331. doi:10.1016/j.cbpa.2008.02.004

58. Koopmanschap, G.; Ruijter, E.; Orru, R. V. A. Beilstein J. Org. Chem. 2014, 10, 544-598. doi:10.3762/bjoc. 10.50 
59. Chebanov, V. A.; Gura, K. A.; Desenko, S. M. In Synthesis of Heterocycles via Multicomponent Reactions I; Orru, R. V. A.; Ruijter, E., Eds.; Springer: Berlin Heidelberg, 2010; Vol. 23, pp 41-84. doi:10.1007/7081_2009_21

60. Soural, M.; Bouillon, I.; Krchňák, V. J. Comb. Chem. 2008, 10, 923-933. doi:10.1021/cc8001074

61. Maiti, B.; Chanda, K.; Selvaraju, M.; Tseng, C.-C.; Sun, C.-M. ACS Comb. Sci. 2013, 15, 291-297. doi:10.1021/co400010y

62. Yugandhar, D.; Srivastava, A. K. ACS Comb. Sci. 2015, 17, 474-481. doi:10.1021/acscombsci.5b00065

63. Vachhani, D. D.; Galli, M.; Jacobs, J.; Van Meervelt, L.; Van der Eycken, E. V. Chem. Commun. 2013, 49, 7171-7173. doi:10.1039/c3cc43418d

64. Moni, L.; Denißen, M.; Valentini, G.; Müller, T. J. J.; Riva, R. Chem. - Eur. J. 2015, 21 , 753-762. doi:10.1002/chem.201404209

65. Vachhani, D. D.; Kumar, A.; Modha, S. G.; Sharma, S. K.; Parmar, V. S.; Van Der Eycken, E. V. Eur. J. Org. Chem. 2013, 1223-1227. doi:10.1002/ejoc.201201587

66. Kumar, A.; Vachhani, D. D.; Modha, S. G.; Sharma, S. K.; Parmar, V. S.; Van Der Eycken, E. V. Synthesis 2013, 45, 2571-2582. doi:10.1055/s-0033-1339474

67. Balalaie, S.; Motaghedi, H.; Bararjanian, M.; Tahmassebi, D.; Bijanzadeh, H. R. Tetrahedron 2011, 67, 9134-9141. doi:10.1016/j.tet.2011.09.089

68. Welsch, S. J.; Umkehrer, M.; Ross, G.; Kolb, J.; Burdack, C.; Wessjohann, L. A. Tetrahedron Lett. 2011, 52, 6295-6297. doi:10.1016/j.tetlet.2011.09.094

69. Ambasana, P. A.; Vachhani, D. D.; Galli, M.; Jacobs, J.; Van Meervelt, L.; Shah, A. K.; Van Der Eycken, E. V. Org. Biomol. Chem. 2014, 12, 8861-8865. doi:10.1039/C4OB01644K

70. Ghabraie, E.; Balalaie, S.; Mehrparvar, S.; Rominger, F. J. Org. Chem. 2014, 79, 7926-7934. doi:10.1021/jo5010422

71. Bienaymé, H.; Bouzid, K. Angew. Chem., Int. Ed. Engl. 1998, 37, 2234-2237. doi:10.1002/(SICI)1521-3773(19980904)37:16<2234::AID-ANIE2234> 3.0.CO;2-R

72. Che, C.; Xiang, J.; Wang, G.-X.; Fathi, R.; Quan, J.-M.; Yang, Z. J. Comb. Chem. 2007, 9, 982-989. doi:10.1021/cc070058a

73. Aouali, M.; Mhalla, D.; Allouche, F.; El Kaim, L.; Tounsi, S.; Trigui, M.; Chabchoub, F. Med. Chem. Res. 2015, 24, 2732-2741. doi:10.1007/s00044-015-1322-Z

74. Huang, Y.; Hu, X.-Q.; Shen, D.-P.; Chen, Y.-F.; Xu, P.-F. Mol. Diversity 2007, 11, 73-80. doi:10.1007/s11030-007-9059-3

75. Parchinsky, V. Z.; Koleda, V. V.; Shuvalova, O.; Kravchenko, D. V.; Krasavin, M. Tetrahedron Lett. 2006, 47, 6891-6894. doi:10.1016/j.tetlet.2006.07.037

76. Akritopoulou-Zanze, I.; Wakefield, B. D.; Gasiecki, A.; Kalvin, D.; Johnson, E. F.; Kovar, P.; Djuric, S. W. Bioorg. Med. Chem. Lett. 2011, 21, 1480-1483. doi:10.1016/j.bmcl.2011.01.001

77. Hieke, M.; Rödl, C. B.; Wisniewska, J. M.; La Buscató, E.; Stark, H.; Schubert-Zsilavecz, M.; Steinhilber, D.; Hofmann, B.; Proschak, E. Bioorg. Med. Chem. Lett. 2012, 22, 1969-1975. doi:10.1016/j.bmcl.2012.01.038

78. Al-Tel, T. H.; Al-Qawasmeh, R. A.; Voelter, W. Eur. J. Org. Chem. 2010, 5586-5593. doi:10.1002/ejoc.201000808

79. Vidyacharan, S.; Shinde, A. H.; Satpathi, B.; Sharada, D. S. Green Chem. 2014, 16, 1168-1175. doi:10.1039/c3gc42130a

80. Burchak, O. N.; Mugherli, L.; Ostuni, M.; Lacapre, J. J.; Balakirev, M. Y. J. Am. Chem. Soc. 2011, 133, 10058-10061. doi:10.1021/ja204016e
81. Guchhait, S. K.; Madaan, C. Org. Biomol. Chem. 2010, 8, 3631-3634. doi:10.1039/c0ob00022a

82. Hatamjafari, F.; Javad, M.; Mohtasham, M.; Chakoli, F. A. Orient. J. Chem. 2012, 28, 1271-1273. doi:10.13005/ojc/280323

83. Guchhait, S. K.; Madaan, C. Synlett 2009, 628-632. doi:10.1055/s-0028-1087915

84. Guchhait, S. K.; Madaan, C.; Thakkar, B. S. Synthesis 2009, 3293-3300. doi:10.1055/s-0029-1216916

85. Rostamnia, S.; Lamei, K.; Mohammadquli, M.; Sheykhan, M.; Heydari, A. Tetrahedron Lett. 2012, 53, 5257-5260. doi:10.1016/j.tetlet.2012.07.075

86. Adib, M.; Mahdavi, M.; Noghani, M. A.; Mirzaei, P. Tetrahedron Lett. 2007, 48, 7263-7265. doi:10.1016/j.tetlet.2007.08.049

87. Tsirulnikov, S.; Kysil, V.; Ivachtchenko, A.; Krasavin, M. Synth. Commun. 2009, 40, 111-119. doi:10.1080/00397910902953331

88. Mouradzadegun, A.; Ma'mani, L.; Mahdavi, M.; Rashid, Z.; Shafiee, A.; Foroumadi, A.; Dianat, S. RSC Adv. 2015, 5, 83530-83537. doi:10.1039/C5RA12307K

89. Krasavin, M.; Tsirulnikov, S.; Nikulnikov, M.; Kysil, V.; Ivachtchenko, A. Tetrahedron Lett. 2008, 49, 5241-5243. doi:10.1016/j.tetlet.2008.06.113

90. Wadhwa, P.; Kaur, T.; Sharma, A. RSC Adv. 2015, 5, 44353-44360. doi:10.1039/C5RA06747B

91. Lee, C.-H.; Hsu, W.-S.; Chen, C.-H.; Sun, C.-M. Eur. J. Org. Chem. 2013, 2201-2208. doi:10.1002/ejoc.201201645

92. Pereshivko, O. P.; Peshkov, V. A.; Ermolat'ev, D. S.; Van Der Eycken, E. V. Synlett 2013, 24, 351-354. doi:10.1055/s-0032-1317986

93. Kysil, V.; Khvat, A.; Tsirulnikov, S.; Tkachenko, S.; Williams, C.; Churakova, M.; Ivachtchenko, A. Eur. J. Org. Chem. 2010, 1525-1543. doi:10.1002/ejoc. 200901360

94. Rahmati, A.; Kouzehrash, M. A. Synthesis 2011, 2913-2920. doi:10.1055/s-0030-1260154

95. Rahmati, A.; Eskandari-Vashareh, M.; Alizadeh-Kouzehrash, M. Tetrahedron 2013, 69, 4199-4204. doi:10.1016/j.tet.2013.03.103

96. Demjén, A.; Gyuris, M.; Wölfling, J.; Puskás, L. G.; Kanizsai, I. Beilstein J. Org. Chem. 2014, 10, 2338-2344. doi:10.3762/bjoc. 10.243

97. Sakhno, Y. I.; Shishkina, S. V.; Shishkin, O. V.; Musatov, V. I.; Vashchenko, E. V.; Desenko, S. M.; Chebanov, V. A. Mol. Diversity 2010, 14, 523-531. doi:10.1007/s11030-010-9226-9

98. Chebanov, V. A.; Saraev, V. E.; Shishkina, S. V.; Shishkin, O. V.; Musatov, V. I.; Desenko, S. M. Eur. J. Org. Chem. 2012, 5515-5524. doi:10.1002/ejoc.201200669

99. Chebanov, V. A.; Sakhno, Y. I.; Desenko, S. M.; Chernenko, V. N.; Musatov, V. I.; Shishkina, S. V.; Shishkin, O. V.; Kappe, C. O. Tetrahedron 2007, 63, 1229-1242. doi:10.1016/j.tet.2006.11.048

100. Chebanov, V. A.; Desenko, S. M. Chem. Heterocycl. Compd. 2012, 48, 566-583. doi:10.1007/s10593-012-1030-2

101. Muravyova, E. A.; Desenko, S. M.; Rudenko, R. V.; Shishkina, S. V.; Shishkin, O. V.; Sen'ko, Y. V.; Vashchenko, E. V.; Chebanov, V. A. Tetrahedron 2011, 67, 9389-9400. doi:10.1016/j.tet.2011.09.138

102. Morozova, A. D.; Muravyova, E. A.; Shishkina, S. V.; Vashchenko, E. V.; Sen'ko, Y. V.; Chebanov, V. A. J. Heterocycl. Chem. 2017, 54, 932-943. doi:10.1002/jhet.2656

103. Ryabukhin, S. V.; Panov, D. M.; Plaskon, A. S.; Grygorenko, O. O ACS Comb. Sci. 2012, 14, 631-635. doi:10.1021/co300082t

104. Rajanarendar, E.; Reddy, M. N.; Raju, S. Indian J. Chem. 2011, 50B, 751-755. 
105.Shafiee, M.; Khosropour, A. R.; Mohammadpoor-Baltork, I.; Moghadam, M.; Tangestaninejad, S.; Mirkhani, V. Tetrahedron Lett. 2012, 53, 3086-3090. doi:10.1016/j.tetlet.2012.04.037

106. Rajanarendar, E.; Murthy, K. R.; Reddy, M. N. Indian J. Chem. 2011, 50B, 926-930.

107. Mandair, G. S.; Light, M.; Russell, A.; Hursthouse, M.; Bradley, M. Tetrahedron Lett. 2002, 43, 4267-4269. doi:10.1016/S0040-4039(02)00709-8

108.Parchinsky, V. Z.; Shuvalova, O.; Ushakova, O.; Kravchenko, D. V.; Krasavin, M. Tetrahedron Lett. 2006, 47, 947-951. doi:10.1016/j.tetlet.2005.11.152

109. Thompson, M. J.; Hurst, J. M.; Chen, B. Synlett 2008, 3183-3187. doi:10.1055/s-0028-1087274

110.Albert, A. Selective Toxicity: the physico-chemical basis of therapy; Springer: Netherlands, 1985. doi:10.1007/978-94-009-4846-4

111.Baeshen, N. A.; Baeshen, M. N.; Sheikh, A.; Bora, R. S.; Ahmed, M. M. M.; Ramadan, H. A. I.; Saini, K. S.; Redwan, E. M. Microb. Cell Fact. 2014, 13, No. 141. doi:10.1186/s12934-014-0141-0 112. Gomaa, E. Z. Braz. Arch. Biol. Technol. 2014, 57, 145-154. doi:10.1590/S1516-89132014000100020

113.Wang, Y.; Ruan, L.; Lo, W.-H.; Chua, H.; Yu, H.-F. Appl. Biochem. Biotechnol. 2006, 132, 1015-1022. doi:10.1385/ABAB:132:1:1015

114. Kamionka, M. Curr. Pharm. Biotechnol. 2011, 12, 268-274. doi:10.2174/138920111794295693

115.Sánchez Blancoa, A.; Palacios Durivea, O.; Batista Péreza, S.; Díaz Montesa, Z.; Pérez Guerra, N. Braz. J. Microbiol. 2016, 47, 665-674. doi:10.1016/j.bjm.2016.04.019

116. Oyeleke, S. B.; Oyewole, O. A.; Egwim, E. C. Adv. Life Sci. 2011, 1, 49-53. doi:10.5923/j.als.20110102.09

117. Markkanen,, P. H.; Bailey, M. J. J. Appl. Chem. Biotechnol. 1974, 24, 93-103. doi:10.1002/jctb.5020240111

118.López-Valdez, F.; Fernández-Luqueño, F.; Ceballos-Ramírez, J. M.; Marsch, R.; Olalde-Portugal, V.; Dendooven, L. Sci. Hortic. (Amsterdam, Neth.) 2011, 128, 499-505. doi:10.1016/j.scienta.2011.02.006

119.Qiao, J.-Q.; Wu, H.-J.; Huo, R.; Gao, X.-W.; Borriss, R. Chem. Biol. Technol. Agric. 2014, 1, No. 12. doi:10.1186/s40538-014-0012-2

120.Lee, S. Y.; Kim, H. U. Nat. Biotechnol. 2015, 33, 1061-1072. doi:10.1038/nbt.3365

121.Stewart, E. J. J. Bacteriol. 2012, 194, 4151-4160. doi:10.1128/JB.00345-12

\section{License and Terms}

This is an Open Access article under the terms of the Creative Commons Attribution License

(http://creativecommons.org/licenses/by/4.0), which permits unrestricted use, distribution, and reproduction in any medium, provided the original work is properly cited.

The license is subject to the Beilstein Journal of Organic Chemistry terms and conditions:

(http://www.beilstein-journals.org/bjoc)

The definitive version of this article is the electronic one which can be found at:

doi:10.3762/bjoc. 13.104 